\title{
The effect of the presence tutorials in the academic performance of the administration students of a university of the north of Mexico
}

\author{
Volumen XIX No (1). Enero-Junio 2019. Pág. 91-107 \\ ISSN: 0121-1048 IMPRESO ISSN: 2422-3220 EN LÍNEA
}

\author{
Armenta Zazueta, Lizeth: \\ Instituto Tecnológico de Sonora, \\ Ramón Corona S/N Col ITSON, \\ CP.85860. Navojoa, Sonora, \\ México. \\ lizeth.armenta@itson.edu.mx
}

\author{
Quiroz Campas, Celia \\ Yaneth \\ Instituto Tecnológico de Sonora, \\ Ramón Corona S/N Col. ITSON, \\ CP.85860. Navojoa, Sonora, \\ México 85860.
}

celia.quiroz@itson.edu.mx

\author{
Cota Valenzuela, Laura \\ Violeta \\ Instituto Tecnológico de Sonora, \\ Km 3, Carr Aeropuerto de \\ Guaymas, 85400 Heroica \\ Guaymas, Sonora, México. \\ lcota@itson.edu.mx
}

\begin{abstract}
The purpose of the study was to identify the effect of the face-to-face tutoring program of undergraduate students in Administration on academic performance, as well as its level of student satisfaction with the program. The research questions were: (a) what are the aspects of the institutional tutoring program that impact on the academic performance of the students? (B) What is the satisfaction stage from the tutored about the tutoring institutional program attended? and (c) what effect does the institutional mentoring program have on the academic performance of administration students during their scholar journey? The methodology used in this study was based on the quantitative approach, non-experimental with a transactional design. 63 eight semester students participated, and they attended the tutoring program. The Pearson correlation test was used for the aspects included in the tutoring program and the academic performance of the students. The results indicate that there is no significant relation between the aspects that the tutorial program covers and the academic performance, however, is a high rate student satisfaction with the tutoring program. In the results of Pearson's correlation test between the aspects of the program and the general average, no significant relation was found in the aspects covered by the program. As a conclusion, the institutional tutoring program does not have a statistically significant relation in the students' academic performance, in contrast to student satisfaction, which was favorable to the tutoring program .
\end{abstract}

Key words: Effect, student, academic performance, satisfaction, tutor

Code JEL: I20, I21, I23

\footnotetext{
- Citar: Armenta Zazueta, Lizeth Quiroz Campas, Celia Yaneth, and Cota Valenzuela, Laura Violeta (2019). The effect of the presence tutorials in the academic performance of the administration students of a University of the North of Mexico. Inquietud Empresarial, XIX (1), 91-107.
} 
The effect of the presence tutorials in the academic performance of the administration students

of a university of the north of Mexico

\title{
El efecto de las tutorías presenciales en el rendimiento académico de los estudiantes de administración de una universidad del norte de México
}

\begin{abstract}
Resumen
El propósito del estudio fue identificar el efecto del programa de tutorías presenciales de la Licenciatura en Aministración de una Universidad en el rendimiento académico, así como su nivel de satisfacción de los estudiantes respecto al programa. Las preguntas de investigación fueron: (a) ¿Cuáles son los aspectos del programa institucional de tutoría que impactan en el rendimiento académico de los estudiantes?, (b) ¿Cuál es el grado de satisfacción del tutorado respecto al programa institucional de tutorías que cursó? y (c) ¿Qué efecto tiene el programa institucional de tutorías en el rendimiento académico de los estudiantes de Administración durante su trayectoria escolar? La metodología se basó en el enfoque cuantitativo, de tipo no experimental y con un diseño transeccional. Participaron 63 estudiantes de octavo semestre, y que acreditaron Tutorías. A partir de los datos obtenidos, se realizaron análisis de tipo descriptivo e inferencial. Se utilizó la prueba de correlación de Pearson para los aspectos incluidos en el programa de tutorías y el rendimiento académico del alumnado, también para la comprobación del rendimiento académico de los participantes. Los resultados de esta investigación indican que no existe una relación significativa entre los aspectos que cubre el programa y el rendimiento académico, sin embargo, hay un alto índice de satisfacción de los estudiantes por el programa de tutorías. En el resultado de la prueba de correlación de Pearson entre los aspectos del programa y el promedio general, no se encontró una relación significativa en los aspectos que cubre el programa. Se concluye que el programa institucional de tutorías no tiene una relación estadísticamente significativa en el rendimiento académico de los estudiantes, en contraste con la satisfacción estudiantil, la cual fue favorable al programa de tutorías.
\end{abstract}

Palabras clave: Efecto, estudiante, rendimiento académico, satisfacción, tutor.

Códigos JEL: I20, I21, I23

\section{INTRODUCTION}

In Mexico, society lives where rhythm goes in function of knowledge. Therefore, education has required a transformation based on a new vision. This must allow integral formation to the students, also must consider the needed competences to learn throughout life (knowing, doing and coexist). All of them, essential to face the challenges and opportunities that support the country's development (Hernandez, 2010).

The Mexican educational system pursuits institutional consolidation through different sheds of knowledge. One of these sheds are the Institutional Tutorial Program. The tutorials have been relevant for the higher education institutions before the problematic scholar desertion, lag and academic performance. Thus, is considered that they could decrease though the tracing and escort of the students in their beginning and scholar journey (ANUIES, 2011).

There is a background of the presence of tutorials trough years, in the teacher's attitude, but it wasn't systemized in superior education until 1972, starting at the Universidad Nacional Autónoma de México 
(Arredondo, 2008). For that tutoring must be driven by teachers that stimulate the social, occupational and intellectual development of the students (Narro y Arredondo, 2013).

Nowadays, tutoring is considered an inherent activity compared to the academic and accompaniment. To that, the establishment of tutoring programs in the superior education institutions are recommended for worldwide organizations as ANUIES, United Nations Educational, Scientific and Cultural Organization (UNESCO) and local organizations like the Comite para la Evaluación de Programas de Pedagogia y Educacion, A.C (CEPPE) and Comites Interinstitucionales para la Evaluacion de la Educacion Superior (CIEES).

\subsection{Problem statement}

One of the problematic issues presented in the superior education institutions in Mexico is the terminal efficiency. Mainly originated by economic, familiar and personal factors and it is based on the academic development presented by the students during their university performance (UNESCO, 2008). Romo (2011) mentions that these difficulties are within the students even before they get into college.

The factors that lay on the terminal efficiency is related with desertion problems and low academic performance from the students with their new scholar environment and future certification problems, influencing into the learning quality and their educational process not following new working schemes (ITSON, 2016).

The terminal efficiency is one of the most common situations affecting the universities, before that, it's been generated by a series of strategies that allow to minimize it and bring within the accomplishment of objectives routed to satisfy the society's needs. Romo (2011), aims through the ANUIES, the development of a document based on the vision about the Higher Education System, including a student integral development program, where it determines that the training in the Higher Education Institutions (HEI) must be entire and accompanied by a tutor so the students can successfully face the needs and opportunities of the country's development.

Among the tutor's functions and faculties, is bringing to the student the educational orientation to raise their academic performance (García, Cuevas, Vales and Cruz, 2012). Likewise, Learning cannot entirely be measured only by observation, it is necessary that the student demonstrate the learned competence (Benitez, 2015), Therefor, evaluation must be through the utilization of instruments that will be transformed in calcifications to measure the student's academic performance.

\subsection{Topic of investigation}

In the Universidad del Norte de México, the tutoring department managers, together with the teachers, have implemented the academic presence tutorials program, according to the guidelines established by the ANUIES. From the beginning, in the 2000s, every seven years improvement have been made to the program, due to the need demonstrate to the institutional indicators (Orduño y Velazco, 2009), and support the improvement of the academic performance indexes of the students and decrease desertion (ITSON, 2016).

At the study university, presence tutorials program brings support to the student in a whole way (ITSON, 2016), through the 
The effect of the presence tutorials in the academic performance of the administration students of a university of the north of Mexico

accompaniment during the first year of college, as well as tracing tutoring and graduated tutoring, to serve the students and train wise graduates with values, attitude, working and study habits. For that, García (2008), like Romo (2011) mention that learning must be supported by the full training principles from the people including the professor as a tutor. Under the academic performance it's an impediment between the IES, not common at this academic level, but is a worrying indicator for the educational authorities and professors as well for the students not accomplishing their goals (Guerra and Borrallo, 2018). It is important to mention that it builds an indicator that allows to provide an approach to the educational reality of an institution (De Miguel, Apodaca, Arias, Escudero, Rodríguez and Vidal, 2002).

\subsection{Study purpose}

The main purpose of this study is to identify the effect of the presence tutorials program in the Administration degree in the Universidad del Norte de Mexico on eighth semester student's academic performance, as well as their satisfaction level as to the different aspects from the program.

\subsection{Investigation questions}

$\Rightarrow \quad$ What are the aspects of the institutional tutoring program that impact on the academic performance of the students?

$\Rightarrow \quad$ What is the satisfaction stage from the tutored about the tutoring institutional program attended?

$\Rightarrow \quad$ What effect has the tutoring institutional program on the academic performance of administration students during their scholar journey?

\section{THEORETICAL FRAMEWORK}

The need of improving the pedagogic practice, is closed related with the fact that it hasn't proved to be innovating, because under some scenarios it's practiced in a deficient way (Rios, 2009) and until today, educational practices have been based on the teacher's transmission, having the human source as a fundamental component (Romo, 2011).

In addition, building an innovating action to the teachers, may allow a better professional role from the teachers. Which enable them to able to get a competence in their knowledge area, assessing situations and suggest different alternatives of action, considering the goals and specific conditions where they performance their teaching action (Rios, 2009).

In order to bring better educational practices, Mexican universities, implement the ANUIES (2011) approach obligatory, being the Institutional Tutoring Program (ITP), aiming to help improving the student's skills, competence and capabilities in addition to accomplish the ANUIES goal: culminate their superior education in the specified time. Then, if the trend in contemporary education is focusing the process of teaching-learning on the student, this affirmation might be precise at its best in the tutoring, which is considered a set of activities that promote learning situations and support the good development of the academic process, in order to get the oriented and motivated students develop their own process (UNESCO, 2015).

From the beginning, the tutoring program emerged as a tool to improve and support the student's formation process in their academic journey that in the future will impact on the 
reduction of the failing, desertion and lag indicators. This program, besides provide different supporting services to the student, promotes learning and the complete develop from all the students. They also expect the teacher as the tutor, but other student could take the role, denominated paired tutoring (De la Cruz, 2017).

According to Serrano (2009), tutoring is considered as an educational strategy to support the complete formation of the student, where the teacher dispute with the students about topics of academic interest, as well as supervising the quality standards, in order to prevent adaptation problem on the new educational context and academic and personal risk situations.

Tutoring is also considered an educational attention form (De la Cruz and Abreu, 2008). The tutor helps the student or a small group of students (no more than 15 members), to help them organize and design their objectives, practice learning techniques, get the group together, and track their college development (Aguilar, 2012).

\section{1. ¿What is and what is not tutoring?}

As it is been mentioned before, at the college level, tutoring aims to bring the new student, individual or group company, through a teacher capable to be a tutor. In order to let the student, develop an ideal personal and professional form (Romo, 2011).

Since tutoring started, claims to be a personalized and individual attention, especially from a tutor with the skills and capabilities to support the students learning. Since then, the tutor is considered as a supporter of the educational contents (Lobato, 2004).
Also, Young and Wringht (2001), define the tutor as a capable and dynamic person, committed to improve other people's skills. In order to accomplish this statement, is important for the tutors to teach and guide their students. Meanwhile, Armenta and Quiroz (2019) explains that the tutors are experienced people with knowledge and commitment to attend their student's activities.

Romo (2004 and 2011) outline that tutoring implies the humanistic conception, therefore seeks varied ways of enrichment of the human being. These ways of enrichment draw from a framework of values that will allow their insertion and social adaptation.

It is important point out tutoring is been defined by experts and it is been reflected by experts from different sociocultural origins. This start from a variety of context to know the magnitude and scope that tutoring can accomplish. Therefore, according to De la Cruz (2017) stablish, if a tutoring definition exists, shouldn't be exactly the one from the manuals, books or another external source, but it must be developed from the university community, that way would be relevant.

According to Romo (2011) tutoring is not a specific nor punctual activity. Neither can solve all the student's problems. It is common to put up tutoring as a magic remedy that will fix a range of the student's situations characteristic from college. It is not appropriate trying to solve inappropriate educational process problems.

Taking the last information, tutoring includes an educational participation, focused on the student and their permanent accompaniment, which in turn allows the teacher to become into the facilitator, counselor and adviser of their professional 
The effect of the presence tutorials in the academic performance of the administration students of a university of the north of Mexico

growth, collaborating with their learning process, encouraging their cultural environment to promote skills and capabilities.

Is mainly performed, through tutoring, the academic feedback process and pedagogic as well provided to keep motivation to the members supporting their learning processes (Guerra y Borrallo, 2017). Likewise, through tutoring, the quality, pertinence and equality of the educational process may be improved (Narro and Arredondo, 2013). Tinto (1992) claims to pay specific attention to the transition process that the students perform from high school to college in their professional education, since that is when the confusion and irregularities problems appear concerning to freedom and independence in the decision making.

Meanwhile Ezcurra (2007) emphasize on provide a bigger approach during the first year of college, since at this stage the student performs deaply that transition, wich may lead the need to take wrong decisions or even quitting school, dropout or failing.

According to De la Cruz, Chehaybar and Abreu (2011), there are a variety of tutoring definitions. Nevertheless they have components in common where the authors match, such as: a) it is a supporting relation, where the student is assisted to achieve personal and academic goals and objectives; b) the relation tutor-student is mutual they both get a benefit; c) the tutor collaborates with his experience on tutoring and knowledge through the years to bring academic, personal and professional support; d) the tutor uses a structured order to measure the achievement and reach of the objectives, teaching and the control mechanism and monitoring.
To support the tutorial action and a whole development of the student it is necessary tutoring, an integration of all the teachers and academic authorities, students services, psychological department, scholarship department, sports, culture, etc., because in order to bring that whole attention, it is required the participation and collaboration of the entire university community to achieve the goals and provide a quality service (ITSON, 2016).

\subsection{Tutoring in College}

Tutoring has become in one of most important topics in universities, which lay on the college teachers (Rodriguez, 2012). From the beginning, tutoring has always been focused on individual attention, certainly under the supervision of a teacher capable to provide knowledge to the student (Romo, 2011). Additionally, Narro and Arredondo (2013), assure that in order to perform the tutoring as a teaching method, is required to admit traditional stereotypes and only academic when tutoring should be specialized on the students as people, not only students, considering a whole attention and not fractioned.

To Martinez (2009) tutoring in college is a valuable tool to the student's formation, since it involves activities aimed to build professionals at a personal, social and academic level. Moreover, Garcia (2008) suggests tutoring as a process of formation actions linked to educational praxis.

Then tutoring, must be understood as a teacher's responsibility in which should exist an interaction between the teacher and the student, with the purpose to support and guide him to accomplish adaptation to a new learning space. Is therefore where the teacher builds his tutoring formation, building and 
supporting the students to create learning scenarios to contribute their academic development with the goal to be the students the ones to build their own learning process (UNESCO, 2011).

Rodríguez (2012) highlights three tutoring models; they also are big models that build subsequent institutional tutoring programs, according to each educational institution requirements, the three models are: the academic model, personal development model and the professional development model. Under these main assumptions and their evolution, colleges provide orientation and services attending the needs pf the students and their academic and professional context.

With this understanding, the obstacles and challenges that teaching in college involve, offer an instructive scenario, as for the freshman students as well for the all the students, the same that according to Lobato and Ilvento (2013) must conclude their studies with a personal and professional project precise and solid to face the real world outside college. All this demand substantial changes and relevant to the spaces and working environments, that is why Neville (2007) suggests the educative models to be valid and the tutor's formation based on competences related to consulting accompaniment and orientation.

\subsection{The Relevance of the College Tutoring}

Fresan and Romo (2011) as well as De la Cruz (2017) agree on college tutoring to be relevant on the last decade, due to the diversity analysis in terms of student's characteristics from their beginning, knowledge, skills, formation, even the age. For that, contemporary tutoring has focused to be a successful mechanism to attend the diversity demanded. It is also important the diversity of the academic profiles the teachers serve as tutors, tracing a reference of changes according to the needs, preferences and particularly the disciplinary formation as a teacher (Castro, Bueno, Barba and Hernandez, 2015).

Besides that, the same society demands professionals that not only have the knowledge related to their academic discipline, but to have the self-regulation, self-control and self-discipline skills, that will help them during all their lives (Ferreiro, 2009). Is where the tutoring applies these mechanisms of personal formation to lead projects about ethical and successful performance into the professional world.

Moreover, Lobato and Ilvento (2013) explain that tutoring is been redesigned to support the construction of life projects that enhance their problem-solving process. This involves two essential factors to personal and professional success, that are: the individual commitment and the tutor accompaniment in the different forms, then being the last one a relevant figure to whole student formation.

\section{Methodology}

\subsection{Participants}

In this study, the population considered was 519 students registered to the Administration degree in the university of study. Such population comprised by both sex students, mainly feminine sex, due to the degree's nature.

For the study's participation, the sample was selected according the academic progress and pathway, for those going through fourth scholar grade, since the tutoring program was 
The effect of the presence tutorials in the academic performance of the administration students of a university of the north of Mexico

taken. According the SITE (2018) data, 63 students relate to the characteristics to participate. Then to develop this study, the collaboration of the students will be requested from the ones admitted on 2015, divided in two groups, the ones going through fourth grade. The mean ages are 21 years, $67 \%$ being feminine sex and $33 \%$ masculine sex.

The study consisted in one type of simple random sampling (Hernandez, Fernández and Baptista, 2010) where all the participants had the same probability to be choose. The attending students were invited by mail, the one registered on their admission to the institution.

\subsection{Instruments}

Two instruments where utilized, one called tutoring program evaluation questionnaire from the student, and collected data to answer question number one, which is: What are the aspects of the institutional tutoring program that impact on the academic performance of the students? This instrument is made up of four sections, where the tutor is expected to guide the student from the moment, he enters the university until he graduates (Benítez, 2015). These sections are the administrative, academic, professional and personal aspects that the program covers. The other instrument called student satisfaction questionnaire, to collect data to answer question number two: what is the satisfaction stage from the tutored about the tutoring institutional program attended? This second instrument was used to measure student satisfaction. To answer the third question: what effect has the tutoring institutional program on the academic performance of administration students during their scholar journey? It was determined through the verification of academic achievement that each student expressed as part of the information requested in the tutoring program evaluation questionnaire.

The level of reliability of the tutoring program evaluation questionnaire from the student and the student satisfaction questionnaire where obtained through the internal consistency with the correlation matrix Cronbach's alpha, applied to 76 students, having as a result a .89 matrix, for that the instrument was considered reliable (Tejedor and Etxeberria, 2006).

\subsection{Process}

Design. This study was carried out under the quantitate focus and the expected results were achieved through the following procedure:

$\Rightarrow \quad$ The permission was asked to the academic authorities in the university of study.

$\Rightarrow \quad$ The instruments answered by the students were digitalized anonymously online, using the institutional plataform SAETI2 (Sistema de Apoyo a la Educación con Tecnologias de Internet).

$\Rightarrow \quad$ The fourth-grade students were informed about the study and the relevance of their contribution, as well as the process to follow.

$\Rightarrow \quad$ A mail was sent to each one of the students to the mail registered by scholar record, a voluntary participant letter to the study, where it specifies the purpose of the study, benefits and relevance of their participation. Including there a link to enter the instruments in case of wanting to be part of the investigation. 
$\Rightarrow \quad$ In no longer than 15 days, the students responded the two instruments described above.

$\Rightarrow \quad$ The academic index was calculated. The final score of the academic performance is according the university's standards, from cero to 100, where 70 is approval (ITSON, 2015). Also categorized according Gomez and Sanchez (2013) with the following ratings: 60-69 low, 70-79 regular, 80-89 good and 90-100 excellent.

$\Rightarrow \quad$ Once all the results were obtained, organization and revision were carried out, to make a database on the SPSS Statistics Version 23 (statistical Package for the Social Sciences) software.

$\Rightarrow \quad$ The analysis was made, followed by the result interpretation and the final report.

\subsection{Data Analysis}

In order to make the data analysis, a variety of descriptive procedures were carried out to measure the study environment. The first consisted in a detailed revision of the data to make sure about the lack of errors in the organization, codification and capture. The Sistema Integral de Trayectorias Escolares (SITE, 2018) was reviewed as well to analyze the mean values, graphics and percentages, in order to obtain the assessment index from the institution. Another technique used was Pearson's correlation, to measure the degree of relationship that two variables have (Armenta and Quiroz, 2019).

The data collected by the first instrument, the sections of which it is composed were analyzed, which are: administrative, academic, professional and personal needs as a professional competence, was made through an average simple. To prepare the indicator of the sections, a general average was calculated, which was related to the student's academic performance.

Concerning the second instrument, with the generated data, an evaluation index was carried out to each of the satisfaction reagents through a simple average. This related to the student's academic performance.

In order to answer the third and last question, which was: what effect has the tutoring institutional program on the academic performance of administration students during their scholar journey? The Pearson correlation was applied to determinate if there is a correlation between the academic performance and the institutional tutorial program's scores. For the verification of the academic performance of the students of each semester of the institution, Pearson correlation was used. For the semi-annual data collection, the Sistema integral de trayectorias escolares (SITE, 2018) was consulted where the generation and semi-annual information is controlled.

\section{RESULTS}

\subsection{Results of the First Investigation Question}

The fist investigation question is: what are the aspects of the institutional tutoring program that impact on the academic performance of the students? There are four aspects covering the institutional tutoring program (administrative, academic, professional and personal aspects) where the descriptive analysis of measures of central tendency were run.

To answer this question, a concentrate of the four aspects covered by the institutional 
The effect of the presence tutorials in the academic performance of the administration students of a university of the north of Mexico

tutoring program is presented: administrative, academic, personal and professional, as well as the mean of the first and second semester of the student, since the means obtained by the student were considered while the student was attending the tutoring program.

A Pearson correlation was made to describe the relation rate of the aspects of the institutional tutoring program, and the mean of the first semester to determine the impact on the student's academic performance in his first semester at the university. The value of the administrative aspect with the mean of the first semester of the students, have a Pearson correlation index of -0.146 ; the value of the academic aspect with the mean of the first semester of the students, they have a Pearson correlation index of -0.212 ; the value of the personal aspect with the mean of the first semester, have a correlation index of 0.044 , and finally, the value of the professional aspect with the first semester had a correlation index of -0.006 . With the data from this study, it is clear that the tutorials are not impacting the academic performance of the students during their first semester (see table 1). Similarly, a Pearson correlation was developed to describe the relation rate of the aspects of the institutional tutoring program and the mean of the second semester, to determine the impact on the academic performance of the student in his second semester at the university.

TABLE 1. CORRELATION OF THE ASPECTS OF THE INSTITUTIONAL TUTORING PROGRAM WITH THE MEANS OF THE FIRST SEMESTER.

\begin{tabular}{lcc}
\hline Tutoring aspect & $\mathbf{N}$ & Correlation mean semester \\
\hline Executive competences and needs & 63 & -.146 \\
Academic competences and needs & 63 & -.212 \\
Personal competences and needs & 63 & -.044 \\
Professional competences and needs & 63 & -.006 \\
\hline
\end{tabular}

Source: own development

The value of the administrative aspect with the mean of the second semester of the students, have a Pearson correlation index of -0.082 ; the value of the academic aspect with the mean of the second semester of the students, have a Pearson correlation index of -0.247 ; the value of personal aspect with the mean of the second semester, have a correlation index of -0.120 , and finally, the value of the professional aspect with the first semester had a correlation index of 0.089 . With this data it is unquestionable that the tutorials did not impact the academic performance of the students during their second semester (see table 2).

TABLE 2. CORRELATION OF THE ASPECTS OF THE INSTITUTIONAL TUTORING PROGRAM WITH THE MEANS OF THE SECOND SEMESTER.

\begin{tabular}{lcc}
\hline Tutoring aspect & $\mathbf{N}$ & Correlation mean second semester \\
\hline Executive competences and needs & 63 & -.082 \\
Academic competences and needs & 63 & -.247 \\
Personal competences and needs & 63 & -.120 \\
Professional competences and needs & 63 & .089 \\
\hline
\end{tabular}

Source: own development

To recognize the level of relevance that has been given the tutoring program, based on the needs of the students, it was asked if tutoring has been carried out at any time based on individual needs, resulting in $63.5 \%$ of the students have taken it while $23 \%$ have not. 
In the rate of consideration that the student has regarding, whether the tutoring in his academic part could support the academic improvement, it was recorded that all students agree, giving a general result of $100 \%$.

\subsection{Results of the Second Investigation Question}

To answer the second investigation question: what is the satisfaction stage from the tutored about the tutoring institutional program attends?, following the questions sequence, the first question was analyzed how many students know the presence tutoring characteristics, obtaining a predominant trend of a $58.7 \%$ percentage of the students considering academic tutoring important, the response frequency was totally satisfied with $66.7 \%$

The results of the tutoring satisfaction instrument were analyzed to determinate the percentage of satisfaction with the development of the tutorial program.

Each questioning was answered according to the experience that each of the students had with their tutors and taking only the most representative values. In order of questions, it was proposed to analyze from the student's experience, if it is clear about the characteristics of the face-to-face tutoring, where the mean was 4.43; it also asked if he considers academic tutoring important, obtaining an average of 4.60 .

In the item on satisfaction on the way he conducted tutoring, the mean result was 4.42 , and the number of sessions, a 4.25 , and a 4.40 for the satisfaction of the time spent by the tutor in each session. Regarding the infrastructure that the institution has to carry out the activities set by the tutoring program; the result was 4.35. Regarding the use of the tutoring session for professional use, the result was 4.30 , academic problems a 4.35 , for the treatment of personal problems, a 2.95 and communication with the tutor in a 4.03.

The student was asked if the tutoring program is satisfactory, the result was 4.33 , so that the result of continuing to work with face-to-face tutoring was 4.05 , and 3.95 in relation to the improvement of academic performance. Taking into consideration, on the scale where one is very low and five very high, there was a general average of 4.12, therefore, the satisfaction expressed by the student towards the tutoring program is highly accepted (see table 3 ).

TABLE 3. MEANS OF THE ANSWERS TO THE SATISFACTION QUESTIONNAIRE OF THE ACADEMIC TUTORING.

\begin{tabular}{|c|c|c|c|c|c|c|}
\hline & Satisfaction items & $\mathbf{N}$ & Min & $\operatorname{Max}$ & Mean & $\begin{array}{l}\text { Standard } \\
\text { deviation }\end{array}$ \\
\hline 1 & From my experience, I have cleared the characteristics of face-to-face tutoring & 63 & 2 & 5 & 4.43 & .777 \\
\hline 2 & I consider academic tutoring important & 63 & 3 & 5 & 4.60 & .610 \\
\hline 3 & The way in which the tutoring was conducted is satisfactory & 63 & 2 & 5 & 4.42 & .737 \\
\hline 4 & The number of tutoring sessions is satisfactory & 63 & 2 & 5 & 4.25 & .842 \\
\hline 5 & $\begin{array}{l}\text { I consider adequate the infrastructure available to the institution to carry out the } \\
\text { activities set out in the mentoring program. }\end{array}$ & 63 & 1 & 5 & 4.35 & .864 \\
\hline 6 & I used the tutoring session to obtain administrative information. & 63 & 2 & 5 & 4.08 & .768 \\
\hline 7 & I used the tutoring session to solve academic questions & 63 & 2 & 5 & 4.30 & .816 \\
\hline 8 & The time my tutor spent on each session we had was satisfactory & 63 & 3 & 5 & 4.40 & .610 \\
\hline 9 & I used the tutoring session to get some personal information. & 63 & 1 & 5 & 3.75 & 1.204 \\
\hline 10 & I used the tutoring session to get some kind of professional information & 63 & 3 & 5 & 4.30 & .710 \\
\hline 11 & My tutor motivates me to work on tutoring in your face-to-face way & 63 & 3 & 5 & 4.33 & .622 \\
\hline
\end{tabular}


The effect of the presence tutorials in the academic performance of the administration students of a university of the north of Mexico

\begin{tabular}{|c|c|c|c|c|c|c|}
\hline 12 & $\begin{array}{l}\text { I believe that face-to-face tutoring can create a climate of trust to expose my } \\
\text { academic problems. }\end{array}$ & 63 & 2 & 5 & 4.35 & .699 \\
\hline 13 & In my experience I dealt with my tutor personal problems & 63 & 1 & 5 & 2.95 & 1.453 \\
\hline 14 & $\begin{array}{l}\text { I believe that by having an assigned tutor I maintain permanent communication } \\
\text { with him / her. }\end{array}$ & 63 & 1 & 5 & 4.03 & .950 \\
\hline 15 & $\begin{array}{l}\text { I believe that with the participation of my tutor I have improved my academic } \\
\text { performance }\end{array}$ & 63 & 2 & 5 & 3.95 & .876 \\
\hline 16 & The face-to-face tutoring program is satisfactory & 63 & 2 & 5 & 4.33 & .741 \\
\hline 17 & I wish to continue working with face-to-face tutoring & 63 & 2 & 5 & 4.05 & .818 \\
\hline
\end{tabular}

Source: own development

\subsection{Results of the Third Investigation Question}

To answer the third question of the study, what effect has the tutoring institutional program on the academic performance of administration students during their scholar journey? Through the Spearman's rank correlation coefficient test the possible relation between the aspects was analyzed which include administrative, academics, personal and professional aspects (in this study the student's average was considered). As shown in table 4, there is no significant relationship between the previously mentioned aspects.

TABLE 4. CORRELATION BETWEEN TOTAL STUDENT AVERAGE AND TUTORING ASPECTS

\begin{tabular}{llc}
\hline \multicolumn{1}{c}{ Tutoring aspect } & N & Correlation with academic performance \\
\hline Average administrative aspect & 63 & $-.253^{*}$ \\
Average academic aspects & 63 & $-.255^{*}$ \\
Average personal aspects & 63 & -.214 \\
Average professional aspects & 63 & .120 \\
\hline
\end{tabular}

Source: own development.

The value of the student's academic performance, with the administrative aspect covered by the tutoring program, has a correlation index of -0.253 ; The value of the student's academic performance with the academic aspect has a correlation of -0.255 ; The value of academic performance with academic performance has a correlation of 0.214 and academic performance with the professional aspect has a correlation of -0.120 .

\section{CONCLUSION}

In response to what are the aspects of the institutional tutoring program that impact on the academic performance of the students? Statistical results show that the four aspects that make up the Institutional Tutoring Program do not generate an impact on student performance. Under that wording,
ANUIES (2011), asserts that the primary intention of the Tutoring Program is to guide and monitor the development of students, through different tools that favor their progress in cognitive aspects, and, therefore, in their academic performance, to improve your personal and social growth. Likewise, although the Tutoring Programs already have established and recognized processes and procedures, with structured indicators, there are tutors that focus mostly on aspects associated with the institution's reports, instead of the student's training process, and coverage of all aspects covered by the program (Rosales, Cedillo and Cedillo, 2015; Lara, 2009).

Meanwhile, in other studies of tutoring and academic performance, Rodríguez (2012) states that the direct actors who participate in 
the tutoring programs, such as: students, teachers and managers, do not have a clear idea of the essential objective of the Program. Very often tutoring is perceived as an academic condition, rather than an action that directs them towards their academic success, and this has to do with the conceptualization that those involved in the tutorial process possess. Thus, Rosales et al. (2015) argue that, according to the meaning established by tutor and tutor, it will be their responsibility and commitment towards the program, generating as a consequence higher expectation of success in the institutional proposal of academic tutoring.

However, in the present study, it can be observed that of the four aspects covered by the Tutoring Program, statistically, they do not generate an impact on the academic performance of the students who participated in the study (see Table 2),

But that does not mean that those same administrative, academic, personal and professional aspects are not executed. On the other hand, Romo (2011), points out that, in some cases, the tutoring, in its ideal way of implementing it, includes integral (with its four aspects) and personalized accompaniment in the student's trajectory. This, the author finds a positive performance, that in Mexican universities evidence of new forms of work between tutor and tutored is generated, to generate new ways in the work of tutoring. This, in the future, will lead to the creation of a new tutorial execution culture.

From the results of this research, it is considered essential to retake the components of the tutoring program and generate the relevant strategies that can support the student in their comprehensive training, as indicated by ANUIES (2011). In the case of the personal aspect, N (2012), states that the tutoring should be planned according to the individual needs of the student. The tutor must offer a unique educational experience that allows the tutor to analyze their ideas, their behavior, their feelings and their attitudes. In relation to the academic aspect, tutoring comprises a fundamental part in the teaching and learning processes of the student (Monge, 2009), as it promotes the development and acquisition of skills that allow learning in their professional training, promoting a successful professional performance in your labor field.

\subsection{Discussion of the Second Research Question}

In response to the second research question: what is the satisfaction stage from the tutored about the tutoring institutional program attends? The results of the Institutional Tutorial Program satisfaction instrument were analyzed to determine the rate of student satisfaction in relation to the program. A high index of satisfaction, since almost $90 \%$ of the participants considered that they received a good contribution from their tutor. Based on these data, Salinas and Martínez (2007), mention that it is essential to consider that student satisfaction represents the central axis of all the processes carried out in the university. The substantial occupation of education is centered on the student, so the objectives must also be considered in relation to the satisfaction that the student issues.

On the other hand, the students affirm that the contribution of the tutoring to improve the academic performance was good, since in the statistical analysis, the 
The effect of the presence tutorials in the academic performance of the administration students of a university of the north of Mexico

average threw a 3.95 , considering a maximum of 5. However, according to their experience as students enrolled in the tutoring program, a high percentage considers that what the program did not provide is experience (see table 3). Given this situation, Monge (2009) considers the importance of confronting the student with the local, regional and even national and international professional reality, as they are scenarios where they can use the acquired knowledge and, in turn, generate experiences that enrich their work.

Castro et al. (2015), highlight that student satisfaction is reflected in the benefits obtained, such as the consideration of the tutor as a guide, receiving valuable and pertinent information about their academic and administrative processes, help in personal matters, generating friendship in the interaction in classmates. They also emphasize that proper compliance in the tutorial action may be the key to student success in the academic field.

Garcia, et al. (2016) contributes that the university activity should be aimed at generating experiences, not only intellectual growth, but also the part social, moral and personal. In addition to focusing on objectives that involve knowledge and procedures, university education must instill values, norms and attitudes outside the classroom.

When the student attends tutorials, De la Cruz et al. (2011), mention that not only the tutoring is favored, but also the tutor, because the interaction with other tutors serves as a driver for the generation of new teaching and learning experiences. The improvement in teaching practice, the contribution of experiences and enrichment of the profession are also encouraged.
Also, Romo (2011) states that when the student is under the tutelage of a teacher, their learning reaches levels of greater significance. Armenta, Zea, Abundis and Quiroz (2019) contributes that the tutor is a central actor in the transformation of the student and is continuously linked in his academic activities. Likewise, the constant update provided by the institution to the tutors and the commitment to exercise the tutoring ethically and responsibly are key performances to develop the tutorial action.

\subsection{Discussion of the Third Research Question}

Regarding the third question: what effect has the tutoring institutional program on the academic performance of administration students during their scholar journey? a Spearman correlation test was performed to know the relationship of each of the aspects covered by the program and the student's academic performance, that is, their academic trajectory. The total average that the students expressed in the Tutoring Program Evaluation Questionnaire from the Student and the average of each of the aspects contained in the tutoring program.

Table 4 shows that statistically there is no significant relationship between academic performance and administrative aspect, nor is there a relationship between academic performance, professional aspect, personal aspect or academic aspect.

In the study by Benítez (2015), on the effect of face-to-face tutoring in nursing students, we worked with the same instruments as this research, and positive correlations were found in the Institutional Program of Academic Tutoring and academic performance. A Spearman correlation analysis, t-student test was established, 
where the 0.459 correlation was obtained, which indicates an association between student satisfaction with tutoring and their academic performance.

Garcia et al. (2012), in their study of the impact of face-to-face and virtual tutoring, ensure that studying and accrediting the program generates a positive impact on the academic performance of students, regardless of the modality. Statistically, the academic performance is higher than that of students who attended and accredited tutoring, than those who did not attend it. These results coincide with the findings of Vales, Ramos and Serrano (2009).

This shows that tutoring is a valuable support for higher education institutions, and in the University of study, administrative and academic aspects have a slightly greater impact on personal and professional aspects. This is not an indicator that other aspects such as professional or personal are not favoring, because all the aforementioned aspects complement each other, but are not being carried out to the same extent. In addition to this, the positive effect of the tutorials, it lies in the balance and development of the tutorial action, in addition to the knowledge and mastery of the tutoring process exercised by the tutor (Fresán and Romo, 2011).

With the present study, we tried to identify the effect of the face-to-face tutoring program of the Bachelor of Administration of the University of Northern Mexico in the academic performance of eighth semester students, as well as their level of satisfaction in terms of aspects that the program covers. With the analysis of the data, it is concluded that the Institutional Tutoring Program, statistically has no significant relation in the academic performance of the students. However, the students' satisfaction with the program is favorable, since the students who completed their tutoring program were satisfied with the content, the development of the sessions, and the performance of the tutor. It is important to mention that these results cannot be conclusive or generalizable. But, what is essential to highlight is the opportunity to provide qualitative information that broadens the reflection on the tutorial practice, based on the experiences of other teachers, and taking into account other factors, involved in the integral development of students, In addition to the implementation of innovative strategies that promote the improvement of educational practices.

\section{REFERENCES}

Aguilar, J. (2012). La configuración de la tutoría en la Universidad Tecnológica de Tijuana: Narrativas docentes. Revista de la Educación Superior [en línea], XLI(4).

Armenta, L., \& Quiroz, C. (2019). Learnings and Motivations Related to Social Service and Volunteer Work in a Community Attention Program of Technological Literacy. The Journal of Social Sciences Research, 5(10), 1450-1454. https://doi.org/10.32861/jssr.510.1450.1454

Armenta, L., Zea, A., Abundis, F., \& Quiroz, C. (2019). Programa de lectoescritura en educación básica. Exploratoris Revista de la Realidad Global, 8(1), 150-154.

Asociación Nacional de Universidades e Institutos de Educación Superior (2011) Innovación curricular en instituciones de educación superior: Pautas y procesos para su diseño y gestión / compilación Lourdes Medina Cuevas, Laura Leticia Guzmán Hernández. México, D.F.: Dirección de Medios Editoriales ANUIES.

Arredondo, J. (2008). La tutoría a estudiantes de Economía en la Universidad de Sonora ( $3^{a}$ ed.). Recuperado de www.eumed.net/tesis/2008/jdal/

Benítez, V. (2015) Efecto del programa de tutoría presencial en el rendimiento académico de estudiantes de enfermería en una universidad pública mexicana. Nova Southeastern University. Tesis consultada el 10 de junio de 2018.

Castro, R., Bueno, S., Barba, C., \& Hernández, M. (2015). Las prácticas de tutoría frente a la sobresaturación del trabajo docente. Revista Culcyt/Educación, 12(55), 122-136. 
De la Cruz, G., \& Abreau, F. (2008). Tutoría en la educación superior: transitando desde las aulas hacia la sociedad del conocimiento. Revista de la educación superior, 37(147), 107-124.

De la Cruz, G., Chehaybar, E. \& Abreau, L. (2011) Tutoría en educación superior: una revisión analítica de la literatura. Revista de la Educación Superior. ISSN: 0185-2760. Vol. XL (1), No. 157, Enero -Marzo de 2011, pp. 189-209.

De la Cruz, G. (2017). Tutoría en Educación Superior: análisis desde diferentes corrientes psicológicas e implicaciones prácticas.CPU-e. Revista de Investigación Educativa,25, $34-59$.

De Miguel, M., Apodaca, P., Arias, J., Escudero, T., Rodríguez, S., \& Vidal, J. (2002). Evaluación del rendimiento en la enseñanza superior. Comparación de resultados entre alumnos procedentes de la LOGSE y del COU. Revista de Investigación Educativa,20 (2), 357-383.

Ezcurra, A. (2007). Los estudiantes de nuevo ingreso: democratización y responsabildad de las instituciones univesitarias. In S. Pimenta (Ed.), Cadernos de pedagogia universitária 2(Ed. rev., pp. 1-57).

Ferreiro, R. (2009). Estrategias didacticas del aprendizaje cooperativo / Cooperative Learning Didactic Strategies: Metodo ELI / ELI Method (2a ed.). Sonora, México: Editorial Trillas Sa De Cv.

Fresán, M., \& Romo, A. (2011). Programas Institucionales de tutoría una propuesta de la ANUIES (3a ed.). México, México: ANUIES 137 p.

García,N. (2008). La función tutorial de la universidad en el actual contexto de la educación superior.Revista Interuniversitaria de Formación del Profesorado,22(1), $21-48$.

García, R., Cuevas, O., Vales, J., \& Cruz, I. (2012). Impacto del programa de tutoría en el desempeño académico de los alumnos del Instituto Tecnológico de Sonora.Revista electrónica de investigación educativa,14(1), 106-121.

Gómez, M. (2012). La percepción de los estudiantes sobre el programa de tutoría académica. Convergencia, 19(58), 209-233.

Gómez, H., \& Sánchez, V. (2013). Indicadores cualitativos para la medición de la calidad en la educación. Educación y Educadores, 16(1), 9-24.

Guerra, M., \& Borrallo, Á. (2018). Tutoría y rendimiento académico desde la perspectiva de estudiantes y profesores de Ciencias de la Salud. Una revisión sistemática. Educación Médica, 19(5), 301-308. https://doi.org/10.1016/j.edumed.2017.03.019

Hernández, C. (2010) "Estrategias de mejoramiento para el logro del programa de tutorías en el nivel superior del IPN" Instituto Politécnico Nacional. Escuela Superior de Comercio y Administración. México, DF.
Hernández, R., Fernández, C., \& Baptista, M. (2014).Metodología de la investigación(3a ed.). Distrito Federal, México: McGraw-Hill Education.

Instituto Tecnológico de Sonora. (2015). Plan de desarrollo institucional 2020. Recuperado 20 mayo, 2017, de https://www.itson.mx/universidad/Paginas/dpi.aspx

Instituto Tecnológico de Sonora. (2016). Programa institucional de tutoría. Formación integral del alumno. Coordinación de desarrollo académico. Recuperado 1 mayo, 2017, de https://www.itson.mx/universidad/Paginas/cda.aspx

Lara, B. (2009). Una aproximación al concepto de tutoría académica en el centro universitario de Ciencias de la Salud. In B. Lara (Ed.), La tutoría académica en educación superior: modelos, programas y aportes. (Ed. rev., pp. 3148).

Lobato, C. (2004). La función tutorial universitaria estrategias de intervención. Papeles salmantinos de educación, 3, 3158.

Lobato, C., \& Ilvento, M. (2013). La orientación y tutoría universitaria una aproximación actual.REDU: Revista de Docencia Universitaria,11 (2), 17-25.

Martínez, M. (2009). La tutoría universitaria ante la creación del espacio Europeo de educación superior.XXI: Revista de Educación,11, 235-244.

Monge, C. (2009). Tutoría y orientación educativa: nuevas competencias.Educación XX1: Revista de la Facultad de Educación,13(1), 224-226.

Narro, J., \& Arredondo, M. (2013). La tutoría. Un proceso fundamental en la formación de los estudiantes universitarios.Perfiles educativos,35(141), 132-151.

Neville, L. (2007). The personal tutor's handbook(Ed. rev.). NY, USA: Macmillan Education UK.

Orduño, Y., \& Velazco, F. (2009). Evaluación de la efectividad del programa tutorías en una institución de educación superior en México.X Congreso Nacional de Investigación Educativa,10, 1-9.

Organización de las Naciones Unidas para la Educación la Ciencia y la Cultura. (2008). Informe de seguimiento de la educación para todos en el mundo (Ed. rev.). Recuperado de http://www.unesco.org/education/gmr2008/capitulo1.pdf

Organización de las Naciones Unidas para la Educación la Ciencia y la Cultura. (2011). La UNESCO y la educación: toda persona tiene derecho a la educación (Ed. rev.). Recuperado de http://unesdoc.unesco.org/images/0021/002127/212715s.p df

Organización de las Naciones Unidas para la Educación la Ciencia y la Cultura. (2015). El informe de seguimiento de la educación para todos en el mundo 2015, educación para 
Armenta Zazueta, Lizeth, Quiroz Campas, Celia Yaneth, and Cota Valenzuela, Laura Violeta

todos 2000-2015: logros y desafíos (Ed. rev.). Recuperado de https://es.unesco.org/news/informe-seguimientoeducacion-todos-mundo-2015educacion-todos-2000-

2015-logros-y-desafios

Ríos, D. (2009). Características personales y profesionales de profesores innovadores. Para la Construcción del Saber, 39(1 у 2), 153-169.

Rodríguez, S. (2012). Manual de tutoría universitaria. Recursos para la acción (2ed.).

Romo, A. (2011).La tutoría: una estrategia innovadora en el marco de los programas de atención a estudiantes (2a ed.). México, México: ANUIES $123 \mathrm{p}$.

Rosales, S., Cedillo, G., \& Cedillo, M. (2015). Tutorías y calidad universitaria.ANFEI digital,(3), 2-9.

Serrano, C. (2009). Acción tutorial y clima escolar en los centros educativos a juicio del profesorado de educación secundaria obligatoria. Pulso: revista de educación, (32), 95-122.

Tejedor, F., \& Etxeberria, J. (2006).Análisis inferencial de datos en educación (Ed. rev.). Recuperado de https://dialnet.unirioja.es/servlet/libro?codigo $=295612$

Tinto, V. (1992). El abandono de los estudios superiores: una nueva perspectiva de las causas del abandono y su tratamiento (Ed. rev.). México, México: Universidad Nacional Autónoma de México.

Vales, J., Ramos, D., \& Serrano, D. (2009). Estudio Comparativo del efecto de las tutorías presencial y a distancia. $X$ Congreso Nacional de Investigación Educativa, 10, 23-35.

Young, C., \& Wright, J. (2001). Mentoring: the components for success. Journal of Instructional Psychology, 28(3), 202207. 